different body banks and, ultimately, to consumers at high prices.

Swanson's solution is simple: scratch the doublespeak and start again. "Body products are property," she writes in her conclusion. "Markets in body products can be harnessed to serve communal goals. The professional donor can be a safe and respected supplier of body products." She makes clear that her aim is to redefine how all tissues - from blood to kidneys - are traded. What she does not quite articulate is that not all body parts are truly equal.

Blood, milk and sperm - and of more recent interest, faeces - are the body's renewables. The removal of a body part, however, entails considerably higher sacrifices. The danger, of course, is that as body products are commodified, so are people. Almost all the voices in her account are doctors, middlemen or regulators; donors and recipients are not represented. We do not hear from prisoners who have been forced to sell their blood, or the many in Pakistan and India who are so desperate for cash that selling a kidney illegally looks like a viable solution.

More importantly, Swanson fails to explore the political economy of the body business. The sale of blood and blood derivatives worldwide generates an annual US $\$ 23.5$ billion, and the United States is the single largest blood exporter in the world. The country also exports corneas, coagu-

lants, bones and

ligaments. Ameri-

cans, in turn, pur-

chase kidneys,

"Everyone seems to be making money on body parts hearts, eggs and except for the livers, and hire donors." surrogate wombs in foreign markets. As the markets cross borders and profits grow, they render the donors invisible. Medical outcomes are important; so, too, is being sure that the donor is unharmed in the exchange. Looking to the banking structures of the past might not be the best way to create ethical supplies in the future.

For scholars interested in the narrow confines of blood, milk and sperm banks in the United States, Swanson's work is a comprehensive historical sweep. However, without an economic analysis, her examination of banking metaphors offers an incomplete picture of a complex issue..

Scott Carney is the author of The Red Market (2011) and a senior fellow at the Schuster Institute for Investigative Journalism.

www.scottcarney.com

CLIMATE SCIENCE

\section{Stratospheric folly}

\section{Tim Kruger examines an argument against injecting aerosols into the atmosphere to counter climate change.}

A s evidence of climate change piles up and pessimism grows over climate negotiations, discussion of geoengineering - deliberate large-scale intervention in Earth's natural systems - is rising up the agenda. In the succinct Can Science Fix Climate Change?, climate scientist Mike Hulme focuses on a proposal to cool Earth by injecting aerosols into the stratosphere to reflect solar radiation. He provides a lucid counterpoint to A Case For Climate Engineering (MIT Press, 2013) by David Keith, a leading proponent of research into this approach.

Hulme believes that deploying stratospheric aerosols is wrong-headed - undesirable, ungovernable and unreliable. $\mathrm{He}$ devotes a chapter to each.

On undesirability, Hulme explains that although the approach would reduce global temperatures, it would also have significant side-effects, such as changing local rainfall patterns. But Hulme compares the downsides with the climate of today, rather than with that of a climate-changed future. This is the equivalent of condemning a drug for having side-effects in healthy people before even considering whether the benefits would outweigh any side-effects in the ill. He thus avoids sullying himself with the consideration of what would constitute the lesser of two evils - a climate-changed world without stratospheric aerosols, or one with them.

Hulme is on much stronger ground in looking at whether such approaches are governable. He argues that "If the deployment of the technology cannot conceivably be adequately governed, then the technology itself should not be researched". He places the ball firmly in the court of those proposing research, urging them to explain up front what regulation should consist of. He puts forward three models - a multilateral United Nations process, a consortium-based regime or deployment by a single country - all of which he finds wanting. Least unfavoured would be a multilateral approach, but Hulme questions whether this could deliver, citing the stalled international climate negotiations as evidence of impracticality. A consortium - a coalition of the willing who agree on how to set the global thermostat - he condemns as too flimsy to govern a technology effectively for the requisite decades. And he views deployment by a single country as deeply unsatisfactory.

It is clear that comprehensive governance needs to be in place before deployment, but

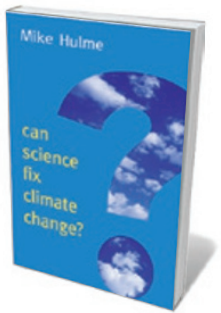

is it necessary before research can be done? Hulme argues that it is, invoking a slipperyslope argument - that once research is started it will lead inexorably to deployment. But although the phenomenon of technologi-
Can Science

Fix Climate Change? A Case Against Climate Engineering MIKE HULME Polity Press: 2014. cal and sociological lock-in is frequently remarked on, so too is the observation that most innovations fail.

Research may show that stratospheric aerosols are far from a satisfactory solution. Hulme argues that their action is unreliable, reeling off a long list of known environmental, social, political and ethical issues, and anticipating others yet unknown. Hulme argues that this list is so overwhelming that it is not worth even starting such an exploration.

Having rejected the case for this technology, Hulme concludes with an alternative plan for tackling climate change. He reiterates the agenda of The Hartwell Paper: A New Direction For Climate Policy After The Crash Of 2009 (LSE, 2010), calling for "reducing weather risks; improving air quality; innovating in the search for cheap, reliable, clean energy". And he emphasizes the moral character of the challenge we face: "It is not climate change that is the ultimate threat to human well-being. It is the lack of virtue."

The question left hanging is whether Hulme's prescription will be adopted. Would that it were.

One can embrace the Hartwell agenda while recognizing that even if it were to succeed, it would lead to a warming world. And while we await a social tipping point - a global renaissance of humility, compassion and justice - we would be well-served by adopting those virtues in consideration of imperfect remedies. Addressing the knotty problems of climate change is more than an issue of virtue or wickedness. Humanity may yet find itself in the position of having to decide which option is the least worst.

Tim Kruger manages the Oxford Geoengineering Programme at the University of Oxford, UK. e-mail:tim.kruger@oxfordmartin.ox.ac.uk 